\title{
Anthropogenic sources and distribution of phosphorus in sediments from the Jaguaribe River estuary, NE, Brazil
}

\author{
Marins, RV., Paula Filho, FJ., Eschrique, SA. and Lacerda, LD.* \\ Laboratório de Biogeoquímica Costeira, Instituto de Ciências do Mar, Universidade Federal do Ceará - UFC, \\ Av. Abolição, 3207, CEP 60165-081, Fortaleza, CE, Brazil \\ *e-mail: 1drude@pq.cnpq.br
}

Received October 6, 2010 - Accepted January 7, 2011 - Distributed 31 August, 2011

(With 2 figures)

\begin{abstract}
This paper estimates annual P emission to the Jaguaribe River estuary, NE Brazil, responsible for approximately $30 \%$ of the country's farmed shrimp production. Emissions increased three times between 2001 and 2006 and reached 43.9 t.year $^{-1}$. These emissions make aquaculture the third main source of $\mathrm{P}$ for this estuary and are much smaller than emissions from agricultural sources and slightly lower than emissions from wastewater. Their relative contribution also increased from $10.5 \%$ to $20.5 \%$. Temporal variability of $\mathrm{P}$ concentrations in estuarine bottom sediments also suggest an increase, but not as evident as the emissions. The spatial distribution and speciation of $\mathrm{P}$ (total $\mathrm{P}$ and inorganic $\mathrm{P}$ ) in sampling stations located upstream and downstream from the main aquaculture area confirmed the importance of this source. Inorganic P was the dominant form present in sediments downstream and showed an increase from $67 \%$ to $75 \%$ of the total $\mathrm{P}$ present in the sediment.
\end{abstract}

Keywords: nutrients, emission, estuary, shrimp culture, wastewaters.

\section{Emissão e distribuição de fósforo de fontes antrópicas no estuário do rio Jaguaribe, Nordeste do Brasil}

\begin{abstract}
Resumo
É apresentada uma estimativa da emissão anual de P para o estuário do rio Jaguaribe, Ceará, Nordeste do Brasil, área responsável por cerca de $30 \%$ da produção total de camarão cultivado no país. As emissões aumentaram por um fator de três entre 2001 e 2006, atingindo 43,9 t.year $^{-1}$. Essa emissão coloca a aquacultura como a terceira fonte principal de $\mathrm{P}$ para esse estuário, sendo bem menor que a emissão de fontes agrícolas e um pouco menor que as emissões por águas servidas. A contribuição relativa da aquacultura também aumentou de 10,5\% a 20,5\%, no mesmo período. A variação temporal das concentrações de $\mathrm{P}$ em sedimentos estuarinos sugere um aumento no período, porém não tão evidente quanto das emissões. A distribuição espacial e a especiação do P (P total e P inorgânico) em estações de coleta localizadas à montante e à jusante da principal área de aquacultura confirmaram a importância desta fonte. $\mathrm{O}$ $\mathrm{P}$ inorgânico foi a forma dominante presente em sedimentos à jusante e mostrou um aumento de $67 \%$ a $75 \%$ do total de $\mathrm{P}$ presente no sedimento.
\end{abstract}

Palavras-chave: nutrientes, emissão, estuário, carcinicultura, águas servidas.

\section{Introduction}

The accumulation of excess nutrients in waters in the continent-ocean continuum, particularly phosphorus, has been correlated with primary production and the eventual onset of eutrophication (Tappin, 2002). Among anthropogenic sources, intensive shrimp aquaculture accounted for environmental impacts associated with the emission of large amounts of $\mathrm{P}$ directly to estuarine waters (Burford et al., 2003; Jackson et al., 2003). For example, in northeast Brazil emission scenarios for 25 estuaries showed that shrimp farming $\mathrm{P}$ contribution varied from $<1$ to $13 \%$ of the total anthropogenic $\mathrm{P}$ emission and in

many areas compares with emissions from waste waters and agriculture (Figueiredo et al., 2005; Lacerda et al., 2008). In the Gulf of California, $P$ derived from intensive shrimp farming reaches $1,600 \mathrm{t}$ annually, representing $7 \%$ of the total P from the region's agriculture. Moreover, it is similar to $\mathrm{P}$ originating from wastewater of nearly 5 million inhabitants (Paéz-Ozuna et al., 2003).

In the Jaguaribe estuarine basin, Ceará State on the Northeastern Brazilian semi-arid coast, freshwater discharge has been affected by the building of dams, water withdrawal for urbanization, agriculture and aquaculture decreasing 
the dilution capacity of the estuary and maximizing the harmful effect of nutrient emissions from anthropogenic sources (Dias et al., 2009). In the estuary, the shrimp pond area increased from 820 ha in 2000 to 1,260 ha in 2003 and 1,640 ha in 2006, whereas the annual yield increased from 5,200 $\mathrm{t}$ in 2001 (6.3 t.ha ${ }^{-1}$.year $\left.{ }^{-1}\right)$ to $11,370 \mathrm{t}$ in 2003 $\left(8.2\right.$ t.ha $^{-1}$.year $\left.{ }^{-1}\right)$. In 2004, there was an increase in the number of farms (98) and pond area (1,520 ha), but a decrease in the annual production $(7,560 \mathrm{t})$ and productivity $\left(5.2\right.$ t.ha $^{-1} \cdot$ year $\left.^{-1}\right)$ due to the spread of typical shrimp illness (Rocha and Rodrigues, 2004). In 2006, production remained around $5.2{\mathrm{t} . h \mathrm{a}^{-1} \text {.year }}^{-1}$ and the total farm area increased to 1,640 ha (Figure 1). During this period, the population increased by $10 \%$ from 80,000 to 88,000 inhabitants. Although $\mathrm{P}$ emissions have also increased, the effects on environment $\mathrm{P}$ concentrations and distribution are still not reported. This study compares the annual $\mathrm{P}$ emissions from intensive aquaculture and other anthropogenic sources and natural processes to the Jaguaribe River estuary with the temporal and spatial variation of $\mathrm{P}$ concentrations in bottom sediments of the estuary, covering the period between 2000 and 2006, when a sharp increase in shrimp farming area occurred in the region.

\section{Material and Methods}

Nutrient loads for coastal watersheds are difficult to measure properly; hence the use of indirect approaches based on emission factors which consider production/consumption parameters of the different anthropogenic sources and the chemical balance of natural processes associated with inventories of natural processes and anthropogenic activities (Tappin, 2002). The most necessary variables can be estimated from surveys and inventories of these activities, such as population parameters, urban and rural area extensions per basin, and agriculture production and fertilizer use. Emission factors have been successfully used to estimate nutrient and pollutant loads at local, regional

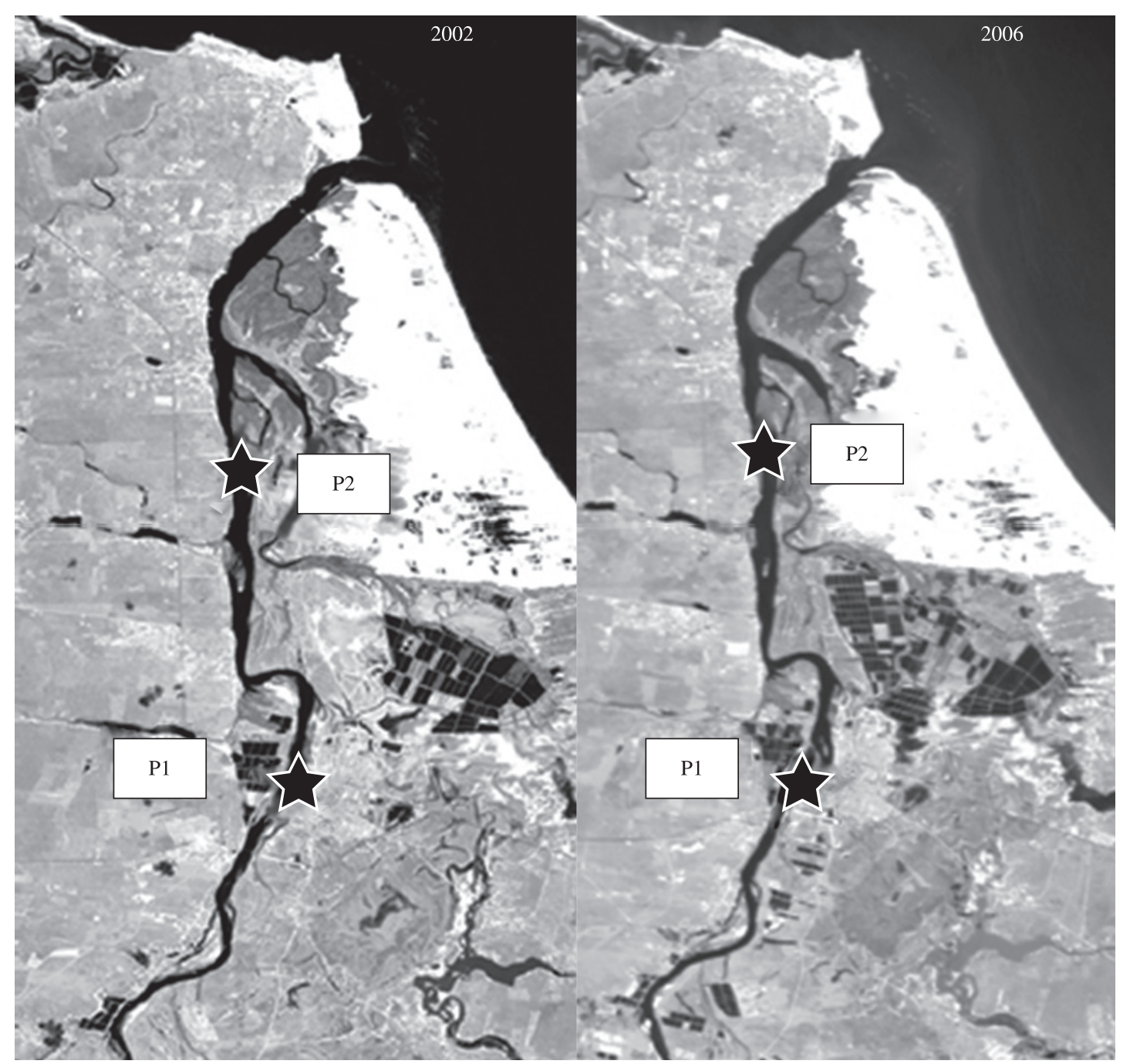

Figure 1. The Jaguaribe River estuary, NE Brazil in 2002 and 2006, showing the expansion of intensive shrimp farming and sampling points. 
and global levels (Lacerda et al., 2006; Martinelli et al., 2002; NRC, 2003), and have been adopted as a standard methodology by various environmental agencies (EEA, 1999; EPA, 2002).

In the Jaguaribe river estuary, an extensive inventory of $\mathrm{N}$ and $\mathrm{P}$ emissions from natural and anthropogenic sources was carried out by Lacerda et al. (2006, 2008) based on statistics from 2001. In general, emission factors (EF) used in that inventory were those available in the literature for each activity or process, but adapted to local conditions whenever necessary. For example, wastewater production per inhabitant, generally calculated based on water consumption parameters of metropolitan areas, was corrected by the actual water consumption rate of the local population (Döll and Hauschild, 2002). Therefore, we use this summary of $\mathrm{P}$ emissions as a comparative basis for the present study. When necessary, as in the case of aquaculture, emissions from different sources were updated using the most recent statistics.

A survey of total and inorganic P concentrations in bottom sediments of the Jaguaribe river estuary were carried out in three campaigns in 2001, 2003 and 2006 to check for alteration in sedimentary $\mathrm{P}$ concentrations. Analyses were performed in sediment sampled by inserting two PVC tubes into the first $20 \mathrm{~cm}$ of the bottom sediments at depositional areas along the river banks located at two selected stations along the estuary. Station P1, at Aracati, is located downstream from the major urban area of the estuary but above the major shrimp farm areas. Station P2, at Raimundinho, is located downstream from the major shrimp farm areas (Figure 1). At station 2, two additional 80-cm-long cores were collected and divided into $10-\mathrm{cm}$ layers to evaluate the temporal variability of $\mathrm{P}$ concentrations. All samples were analyzed in duplicate, averages presented are thus from $n=4$. Samples were stored frozen and analyzed using established protocols (Marins et al., 2007). Total P was obtained after the sample ignition at $550{ }^{\circ} \mathrm{C}$ during 12 hours. Ashes were digested by $\mathrm{HCl} 1.0 \mathrm{M}$ under stirring. Another sub-sample was directly treated with $\mathrm{HCl} 1.0 \mathrm{M}$ at room temperature, and under constant stirring for inorganic $\mathrm{P}$ determinations. This method using individual subsamples reduces the material losses typical of sequential analysis of $\mathrm{P}$ fractions (Berner and Rao, 1994; Koch et al., 2001; Marins et al., 2007).

\section{Results and Discussion}

The results comparing emission inventories for 2001 and 2006 are summarized in Table 1 and show that today, emissions from natural sources $\left(23.3\right.$ t.year $\left.^{-1}\right)$ are 9 times lower than those from anthropogenic sources (191 t.year ${ }^{-1}$ ). Agriculture shows the largest load and emission yield (82.8 t.year ${ }^{-1} ; 47.7$ kg.km-2.year ${ }^{-1}$ ), whereas wastewaters (44.7 t.year ${ }^{-1} ; 25.8 \mathrm{~kg} \cdot \mathrm{km}^{-2}$.year $\left.{ }^{-1}\right)$ and aquaculture (43.9 t. year ${ }^{-1}, 25.3 \mathrm{~kg} \cdot \mathrm{km}^{-2}$.year ${ }^{-1}$ ) rank second and third among P sources followed by husbandry (19.0 t.year ${ }^{-1} ; 11.0 \mathrm{~kg}$. $\mathrm{km}^{-2}$.year ${ }^{-1}$ ). Urban runoff plus solid waste disposal shows the smallest contribution $\left(0.3\right.$ t.year ${ }^{-1} ; 0.2 \mathrm{~kg} \cdot \mathrm{km}^{-2}$.year $\left.{ }^{-1}\right)$.
Although aquaculture accounts for only $20.5 \%$ of total $\mathrm{P}$ emissions, the location of farms adjacent to estuarine areas results in direct inputs to estuarine waters effectively increase environmental concentrations. Most other emissions go firstly to soils before eventually reaching the estuarine waters (David et al., 2009).

Natural processes contributing with $\mathrm{P}$ to the Jaguaribe River Estuary are soil loss and atmospheric deposition is dependent on the basin area, soil type and retention capacity and climate. Soil loss contributed to this estuary 11.2 t.year $^{-1}$ in the 2001 inventory whereas atmospheric deposition contributed with 12.1 t.year $^{-1}$. Since no significant soil use or climate change occurred between 2000-2006, no significant changes in $\mathrm{P}$ emissions from these natural processes can be statistically predicted. The total natural load of P reaches 23.9 t.year ${ }^{-1}\left(13.7 \mathrm{~kg} \cdot \mathrm{km}^{-2}\right.$.year $\left.{ }^{-1}\right)$, with $55 \%$ from soil loss and $45 \%$ from atmospheric deposition. The relative contributions of natural sources to the total P load however, decreased from $13.1 \%$ in 2001 to $10.9 \%$ in 2006 (Table 1).

Their relative contribution of the anthropogenic $\mathrm{P}$ sources varies depending on the degree of urbanization, population size and extension of agricultural lands and shrimp pond area. Invariably, none of these activities` effluents receive any treatment before being released into the local environment. Non-mechanized agriculture present at the Jaguaribe River estuarine basin, is mostly dependent on crop type and size of cultivated area. Major P losses from the regional cultures are from cashew nuts, manioc and corn (Lacerda et al., 2008) and reach 82.8 t.year $^{-1}$ $\left(47.7 \mathrm{~kg} \cdot \mathrm{km}^{-2} \cdot \mathrm{year}^{-1}\right)$. No significant changes in major crop types or cultivated areas occurred in the Jaguaribe river lower basin. Therefore, no difference in $\mathrm{P}$ emissions from agriculture occurred over the past 6-years period (Table 1).

Livestock in the Jaguaribe estuarine basin is reared extensively and is dominated by bovine. Therefore, the existing inventory considered that $\mathrm{P}$ emitted from this practice will always pass through soils prior to reaching rivers. Emission of $\mathrm{P}$ from the region's husbandry was 10.7 t.year ${ }^{-1}$ in $2001\left(6.2 \mathrm{~kg} \cdot \mathrm{km}^{-2}\right.$.year $\left.{ }^{-1}\right)$. Unlike agriculture, increasing bovine and ovine cattle resulted in a 1.8 increase of $\mathrm{P}$ emission from this source to 19.0 t.year $^{-1}$ in 2006 (Table 1).

Urban areas are diffuse sources of P to surface waters. When no treatment plants exist, nutrient loads from this source are directly proportional to the population and the amount of water used per inhabitant as $\mathrm{P}$ concentrations in urban wastes, wastewater and runoff vary within a narrow range, resulting in emission factors (EFs) directly derived from population parameters (Smith et al., 1997). The population in the estuarine basin increased less than $10 \%$ from 2001 to 2006 . Therefore, $\mathrm{P}$ emissions from wastewater varied little, increasing by about $5 \%$ only from 42.5 to 44.7 t.year ${ }^{-1}$. Urban runoff and solid waste disposal are relatively small sources of P compared to wastewaters, therefore any increase in $\mathrm{P}$ emission from these sources due to population increase is statistically undetectable, for 
the short period considered and methods used, remaining at about 0.3 t.year ${ }^{-1}$ only (Table 1 ).

Intensive shrimp aquaculture in the Jaguaribe River estuary uses large amounts of fertilizers and feed to maintain one of the highest productivity rates reported for the activity (about 6.2 t.ha.year ${ }^{-1}$ ). Super-phosphate is the major form of $\mathrm{P}$ fertilization with an application reaching $25 \mathrm{~kg}$.ha ${ }^{-1}$.year ${ }^{-1}$, assuming the local typical food conversion rates of 1.5 to 1.8 (Lacerda et al., 2006). Despite the economic importance of the activity, there are few studies estimating $\mathrm{P}$ emission from these farms. However, since intensive shrimp farming procedures are similar worldwide, it is reasonable to use EFs estimated for other areas in the. Emission factors for P estimated that farms worldwide vary only 2.5 times reaching an average of about $20 \mathrm{~kg} \cdot \mathrm{ha}^{-1} \cdot \mathrm{year}^{-1}$. This figure is very similar to the EFs derived from the Jaguaribe farms (Figueiredo et al.,
2005; Lacerda et al., 2006). From 2001 to 2006, P loads varied mostly following the increase in the total pond area. In 2004, however, increasing water renewal to prevent illnesses from 10 to $20 \%$ daily also resulted in larger EF. However, typical producing conditions were returned after 2004. The total P emission increased from 21.9 t.year $^{-1}$ in 2001 to 33.7 t.year ${ }^{-1}$ in 2003 (54\%) and 43.9 tP.year $^{-1}$ in $2006(100 \%)$.

Marins et al. (2007) in a sedimentological survey of the Jaguaribe estuary characterized the sediments from the two sampling stations as siliciclastic (80-90\% d.w.), suggesting a dominant contribution from terrestrial sources and particularly enriched in organic matter, especially at the station downstream from the creek receiving shrimp farm effluents $(6.4 \pm 0.2 \%$ d.w., $\mathrm{n}=5)$ relative to the upstream station P1 (3.7 $\pm 0.4 \% \%$ d.w., $\mathrm{n}=5)$. Figure 2 shows total and inorganic $\mathrm{P}$ in bottom sediments measured in 2001,

Table 1. Comparison of annual emission $\left(\mathrm{t} . \mathrm{yr}^{-1}\right)$, emission yields $\left(\mathrm{kg}_{\mathrm{km}} \mathrm{km}^{-2} \cdot \mathrm{yr}^{-1}\right)$ and relative contribution ( $\left.\mathrm{RC} \%\right)$ of $\mathrm{P}$ for the Jaguaribe River Estuary, NE Brazil in 2001 and 2006.

\begin{tabular}{|c|c|c|c|c|c|c|}
\hline \multirow{2}{*}{$\begin{array}{c}\text { Source } \\
\text { category }\end{array}$} & Emission & Yield & $\mathbf{R C}$ & Emission & Yield & $\mathbf{R C}$ \\
\hline & \multicolumn{3}{|c|}{2001} & \multicolumn{3}{|c|}{ 2006 $^{\mathrm{a}}$} \\
\hline Non-agriculture soils denudation & 11.2 & 6.5 & 6.3 & 11.2 & 6.5 & 5.2 \\
\hline Atmospheric deposition & 12.1 & 7.0 & 6.8 & 12.1 & 7.0 & 5.7 \\
\hline Agriculture & 82.8 & 47.7 & 46.4 & 82.8 & 47.7 & 38.7 \\
\hline Husbandry & 10.7 & 6.2 & 6.0 & 19.0 & 11.0 & 8.9 \\
\hline Wastewaters disposal & 42.5 & 24.5 & 23.8 & 44.7 & 25.8 & 20.9 \\
\hline Urban runoff and waste disposal & 0.3 & 0.2 & 0.2 & 0.3 & 0.2 & 0.1 \\
\hline Intensive shrimp farming & 18.8 & 10.8 & 10.5 & 43.9 & 25.3 & 20.5 \\
\hline Total & 178.4 & 102.9 & 100 & 214 & 123.5 & 100 \\
\hline
\end{tabular}

${ }^{a}$ Updated using the newest available figure based on procedures in Lacerda et al. (2008).
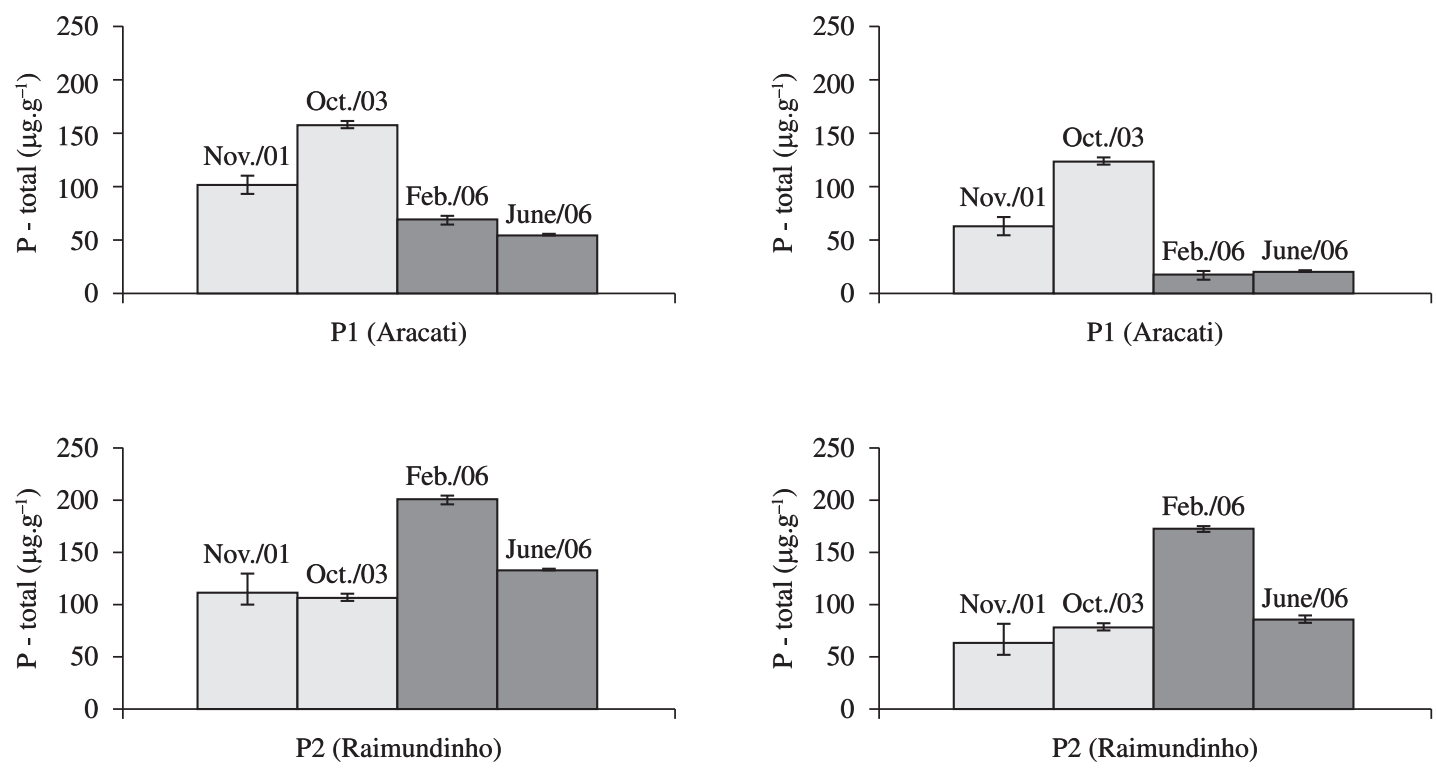

Figure 2. Total and inorganic phosphorus distribution in sediments collected upstream and downstream the creek mouth receiving shrimp farming effluents at the Jaguaribe River estuary, NE Brazil, from 2001 to 2006. Error bars represents differences from duplicate samples $(n=4)$. 
2003 and 2006 at the two sampling stations (see Figure 1 for location). Inorganic P is believed to better represent anthropogenic sources. Station P1, is located downstream from the major town of the estuary, Aracati, with nearly 70,000 inhabitants and showed total P $\left(101-157 \mathrm{mg} \cdot \mathrm{g}^{-1}\right.$, in 2001-2003) and inorganic P (62 - $125 \mathrm{mg} . \mathrm{g}^{-1}$, in 20012003 ) concentrations in sediments actually lower in 2006 (18 - $55 \mathrm{mg} \cdot \mathrm{g}^{-1}$ and $20-70 \mathrm{mg} \cdot \mathrm{g}^{-1}$, for total P and inorganic $\mathrm{P}$ respectively), notwithstanding the inputs from wastewaters, agriculture and husbandry located upstream of this station. Downstream from the canal which drains the shrimp farms, $\mathrm{P}$ concentrations were higher from 2001 to 2003 (106 - $110 \mathrm{mg} \cdot \mathrm{g}^{-1}$ and $65-78 \mathrm{mg} \cdot \mathrm{g}^{-1}$, for total P and inorganic P respectively) than in $2006\left(134-201 \mathrm{mg} \cdot \mathrm{g}^{-1}\right.$ and $86-174 \mathrm{mg} \cdot \mathrm{g}^{-1}$, for total and inorganic P respectively). The observed difference between February (rainy season) and June (dry season) in 2006 may be explained by different sedimentary and hydrological dynamics between the two seasons and be responsible for the differences observed in $\mathrm{P}$ concentrations. However, more detailed studies are needed to clarify these differences. Partitioning between $\mathrm{P}$ species was also different at the two sites. Inorganic P was the dominant form in sediments downstream from the shrimp farm and increased from $67 \%$ to $75 \%$ between $2001-2003$ and 2006. At station P1, inorganic P accounted for $70 \%$ of the total P in 2001-2003, but was lower ( 30\%) in 2006.

Phosphorous distribution in sediment cores collected downstream from the creek mouth receiving shrimp farm effluents close to station P2 confirms the results by confirming superficial sediments. The site presents an average sedimentation rate (excess ${ }^{210} \mathrm{~Pb}$ method) of $0.31 \mathrm{~cm}$. year $^{-1}$ (Marins et al., 2007). The vertical distribution of $\mathrm{P}$ concentrations is in agreement with the results found in the surface sediments. Concentrations of total $\mathrm{P}$ averaged $170 \mathrm{mg} \cdot \mathrm{g}^{-1}$ in the core`s bottom layer at $60-70 \mathrm{~cm}$, around 170-200 years ago, roughly corresponding with the establishment of the first urban nucleus in the region. $10 \mathrm{~cm}$ deep from the surface, concentrations increased and remained relatively constant around $185 \mathrm{mg} \cdot \mathrm{g}^{-1}$. From $10 \mathrm{~cm}$ to the surface, roughly corresponding to the past two decades, total $\mathrm{P}$ concentrations increased further and reached an average of $205 \mathrm{mg} \cdot \mathrm{g}^{-1}$. Similarly, concentrations of inorganic $\mathrm{P}$ were relatively constant (average $100 \mathrm{mg} \cdot \mathrm{g}^{-1}$ ) throughout the core from the bottom to about $10 \mathrm{~cm}$ of depth. In the superficial $5 \mathrm{~cm}$ layer (corresponding to the past 15 years), $\mathrm{P}$ concentrations increased by about $15 \%$ to $115 \mathrm{mg} \cdot \mathrm{g}^{-1}$.

Differences of concentration between upstream and downstream stations, as well as between the bottom and surface sediments of the core collected in station 2 , reinforces the importance of aquaculture as the dominant $\mathrm{P}$ source for the estuary, even considering that the activity contributes with $20.5 \%$ of the total $\mathrm{P}$ emissions when all the other anthropogenic sources are taken into account. This suggests that releasing effluents directly into the estuary may be a determining factor for the importance of shrimp farming.
Biao et al. (2004) showed that inorganic P exports from shrimp farms in China is not diminished by sedimentation ponds resulting in a direct relationship between $\mathrm{P}$ concentrations in receiving creek waters and the pond management strategy, mostly the water renewable time. They also reported continuous increases in the $\mathrm{P}$ concentration after installing it in shrimp farms. Increasing $\mathrm{P}$ concentrations have also been recorded from five major aquaculture sites in the Philippines (David et al., 2009). Distribution along dated sediment cores provided evidence similar to our study showing aquaculture as recent, but already responsible for a significant part of the $P$ contribution, relative to other anthropogenic sources and probably responsible for the increase in $\mathrm{P}$ concentrations observed in the sediments in the estuary.

Shrimp farm P emission increased from $10 \%$ to $20 \%$ of the total in the Jaguaribe estuary between 2001 and 2006, relative to the other anthropogenic $\mathrm{P}$ sources. The release of effluents directly to mangrove creek waters draining into the Jaguaribe River estuary makes shrimp farm effluents more important in terms of the total load of $\mathrm{P}$ to the estuary and is probably the main cause of the direct response to the increase in sediment $\mathrm{P}$ concentrations to shrimp farm areas. On the other hand, the release of $P$ from wastewater in open air andlor underground aseptic sinks, and from agriculture and even husbandry whose emissions nearly doubled in the period, released in soils prior to reaching river waters, cannot be directly correlated to changes in the sediment $\mathrm{P}$ content.

Acknowledgements - This study was supported by CNPqINCT Proc. $n^{\circ}$ 573.601/2008-9 and the FINEP/RECARCINE Initiative.

\section{References}

BERNER, RA., RAO, JL., 1994. Phosphorus in sediments of the Amazon River and estuary: Implications for the global flux of phosphorus to the sea. Geochimica et Cosmochimica Acta, vol. 58, p. 2333-2339. http://dx.doi.org/10.1016/0016-7037(94)90014-0

BIAO, X., ZHUHONG, D. and XIAORONG, W., 2004. Impact of intensive shrimp farming on the water quality of the adjacent coastal creeks from Eastern China. Marine Pollution Bulletin, vol. 48, p. 543-553. PMid:14980470. http://dx.doi.org/10.1016/j. marpolbul.2003.10.006

BURFORD, MA., COSTANZO, SD., DENNISON, WC., JACKSON, CJ., JONES, AB., MCKINNON, AD., PRESTON, NP. and TROTT, LA., 2003. A synthesis of dominant ecological processes in intensive shrimp ponds and adjacent coastal environments in NE Australia. Marine Pollution Bulletin, vol. 46, p. 1456-1469. http://dx.doi.org/10.1016/S0025-326X(03)00282-0

DAVID, CPC., STA MARIA, YY., SIRINGAN, FP., REOLITA, JM., ZAMORA, PB., VILLANOY, CL., SOMBRITO, EZ. and AZANZA, RV., 2009. Coastal pollution due to increasing nutrient flux in aquaculture sites. Environmental Geology, vol. 58, p. 447454. http://dx.doi.org/10.1007/s00254-008-1516-5

DIAS, FJS., MARINS, RV. and MAIA, LP., 2009. Hydrology of a well-mixed estuary at the semi-arid Northeastern Brazilian coast. Acta Limnologica Brasiliensia, vol. 21, p. 377-385. 
DÖLL, P., HAUSCHILD, M., 2002. Model-based scenarios of water use in two semi-arid Brazilian states. Regional Environmental Change, vol. 2, p. 150-162. http://dx.doi.org/10.1007/s10113002-0046-z

Environmental Protection Agency - EPA, 2002. National Recommended Water Quality Criteria. Environmental Protection Agency. Office of Water. EPA-822-R-02-047.

European Environmental Agency - EEA, 1999. Nutrients in European Ecosystems. Luxemburg: European Environmental Agency,Office for Official Publications of the European Communities. 219 p. Environmental Assessment Report, no. 4.

FIGUEIREDO, MCB., ARAÚJO, LFP., GOMES, RB., ROSA, MF., PAULINO, WD. and MORAIS, LFS., 2005. Impactos ambientais do lançamento de efluentes da carcinicultura em águas interiores. Engenharia Sanitária and Ambiental, vol. 10, p. 167-174.

JACKSON, C., PRESTON, NP., THOMPSON, P. and BURFORD, M., 2003. Nitrogen budget and effluent nitrogen components at an intensive shrimp farm. Aquaculture, vol. 218, p. 397-411. http:// dx.doi.org/10.1016/S0044-8486(03)00014-0

KOCH, MS., BENZ, RE., RUDNICK, DT., 2001. Solid-phase phosphorus pools in highly organic carbonate sediments of Northeastern Florida Bay. Estuarine, Coastal and Shelf Science, vol. 52, p. 279-291. http://dx.doi.org/10.1006/ecss.2000.0751

LACERDA, LD., VAISMAN, AG., MAIA, LP., CUNHA, E. and SILVA, CAR., 2006. Relative importance of nitrogen and phosphorus emissions from shrimp farming and other anthropogenic sources for six estuaries along the NE Brazilian coast. Aquaculture, vol. 253, p. 433-446. http://dx.doi.org/10.1016/j.aquaculture.2005.09.005

LACERDA, LD., MOLISANI, MM., SENA, D. and MAIA, LP., 2008. Estimating the importance of natural and anthropogenic sources on $\mathrm{N}$ and $\mathrm{P}$ emission to estuaries along Ceará State
Coast NE Brazil. Environmental Monitoring and Assessment, vol. 141, p.149-164

MARINS, RV., PAULA-FILHO, FJ. and ROCHA, CAS., 2007. Geoquímica de fósforo como indicadora da qualidade ambiental e dos processos estuarinos do rio Jaguaribe - costa nordeste oriental brasileira. Química Nova, vol. 30, p. 1208-1214.

MARTINELLI, LA., SILVA, AM., CAMARGO, PB., MORETTI, LR., TOMAZELLI, AC., SILVA, DML., FISHER, EG., SONODA, KC. and SALOMÃO, MSMB., 2002. Levantamento de cargas orgânicas lançadas nos rios do Estado de São Paulo. Biota Neotropica, vol. 2, p.1-18.

National Research Council - NRC, 2003. Clean Coastal Waters. Understanding and Reducing the Effects of Nutrient Pollution. Washington: National Research Council, National Academy Press. 573 p.

PÁEZ-OZUNA, F., GRACIA, A., FLORES-VERDUGO, F., LYLE-FRITCH, LP., ALONSO-RODRÍGUEZ, R., ROQUE, A, and RUIZ-FERNÁNDEZ, AC., 2003. Shrimp aquaculture and the environment in the Gulf of California ecoregion. Marine Pollution Bulletin, vol. 46, p. 806-815. http://dx.doi.org/10.1016/ S0025-326X(03)00107-3

ROCHA, IP. and RODRIGUES, J., 2004. O agronegócio do camarão cultivado em 2003. Recife: Associação Brasileira de Criadores de Camarão. 54 p.

SMITH, RA., ALEXANDER, RB. and WOLMAN, MG., 1997. Regional interpretation of water monitoring data. Water Resources Research, vol. 33, p. 2781-2798. http://dx.doi. org/10.1029/97WR02171

TAPPIN, AD., 2002. An examination of the fluxes of nitrogen and phosphorus in temperate and tropical estuaries: Current estimates and uncertainties. Estuarine Coastal and Shelf Science, vol. 55, p. 885-901. http://dx.doi.org/10.1006/ecss.2002.1034 